\title{
New data on the spider fauna of Iran (Arachnida: Aranei), part III
}

\section{Новые данные о фауне пауков Ирана (Arachnida: Aranei), часть III}

\author{
Alireza Zamani ${ }^{1}$, Omid Mirshamsi ${ }^{2} 3^{*}$, Parisa Rashidi², \\ Yuri M. Marusik ${ }^{4,5,6}$, Majid Moradmand ${ }^{7}$, Angelo Bolzern ${ }^{8}$ \\ А. Замани ${ }^{1}$ О. Миршамси ${ }^{2,}$, П. Рашиди², Ю.М. Марусик ${ }^{4,5,6}$, \\ М. Морадманд ${ }^{7}$, А. Бомьцерн ${ }^{8}$

\footnotetext{
${ }^{1}$ School of Biology, College of Sciences, University of Tehran, Tehran, Iran.

${ }^{2}$ Department of Biology, Faculty of Sciences, Ferdowsi University of Mashhad, Mashhad, Iran.

${ }^{3}$ Research Department of Zoological Innovations (RDZI), Institute of Applied Zoology, Faculty of Sciences, Ferdowsi University of Mashhad, Mashhad, Iran.

${ }^{4}$ Institute for Biological Problems of the North RAS, Portovaya Str. 18, Magadan 685000, Russia.

${ }^{4}$ Институт биологических проблем Севера ДВО РАН, ул. Портовая , 18, Магадан 685000, Россия.

${ }^{5}$ Department of Zoology \& Entomology, University of the Free State, Bloemfontein 9300, South Africa.

${ }^{6}$ Far Eastern Federal University, Sukhanova 8, Vladivostok 690950, Russia.

${ }^{7}$ Department of Biology, Faculty of Sciences, University of Isfahan, Isfahan, Iran.

${ }^{8}$ Naturhistorisches Museum Basel, Augustinergasse, Switzerland.

"Corresponding author: mirshams@um.ac.ir
}

KEY WORDS: Arachnida, Araneae, fauna, Miturgidae, new faunistic records, Iranian Plateau.

КЛЮЧЕВЫЕ СЛОВА: Arachnida, Araneae, фауна, Miturgidae, новые фаунистические находки, Иранское плато.

ABSTRACT. The paper is the third contribution in the series devoted to spider species new to the fauna of Iran. The family Miturgidae, seven genera (Agelescape, Dictyna, Firmicus, Paracedicus, Poecilochroa, Prochora, Sidydrassus) and 30 species are recorded from Iran for the first time. The hitherto doubtful Iranian record of Benoitia lepida (O. Pickard-Cambridge, 1876) (Agelenidae) is confirmed by the specimens newly collected from Khorasan-e Razavi Prov. A map of collecting localities is provided and 15 species are illustrated by digital photos.

РЕЗЮМЕ. Настоящая работа является третьим сообщением в серии статей посвященных новым видам пауков для фауны Ирана. Семейство Miturgidae, семь родов (Agelescape, Dictyna, Firmicus, Paracedicus, Poecilochroa, Prochora, Sidydrassus) и 30 видов отмечаются впервые для Ирана. Ранее считавшаяся сомнительной находка Benoitia lepida (O. Pickard-Cambridge, 1876) (Agelenidae) подтверждена материалом, собранным в провинции Хорасан-Резави. Приводится карта с указаниями точек находок всех видов, и 15 проиллюстрирваны цифровыми фотографиями.

\section{Introduction}

The present paper is the third contribution in the series devoted to a comprehensive faunistic study of Iranian spiders. To date, 562 spider species of 243 genera have been recorded from Iran [Zamani et al., 2016]. Although there are several recent arachnological publications dealing with new species or records of the Iranian fauna [e.g., Kashefi et al., 2013; Mirshamsi et al., 2013a,b, 2015; Logunov et al., 2013; Marusik et al., 2014a,b; Zamani, 2015; Zamani et al., 2014, 2015; Marusik, Zamani, 2015b], comprehensive taxonomic surveys and/or large-scaled faunistic works are scarce [e.g., Logunov et al., 2002; Ono, Martens, 2005; Tanasevitch, 2008, 2009; Moradmand, Jäger, 2011; Marusik, Zamani, 2015a]. There are still many regions of the country that remain uninvestigated, especially the western and south-eastern territories. In the recent checklist by Mirshamsi et al. [2015], it was suggested that the total species diversity of Iranian spiders could be more than 1000 species. As a result of the two previous parts of the current series, three families (Liocranidae, Mimetidae and Mysmenidae), 21 genera and 60 species have been recorded from Iran for the first time [Zamani et al., 2014, 2015]. The main goal of the present paper is to provide faunistic records for 30 spider species that are new to the fauna of Iran, and thereby to raise the total number of Iranian spider species to 592 .

\section{Material and methods}

The bulk of the material treated in this paper was collected by the authors and their colleagues from different Prov.s of Iran from 1973 till now (Map). Speci- 


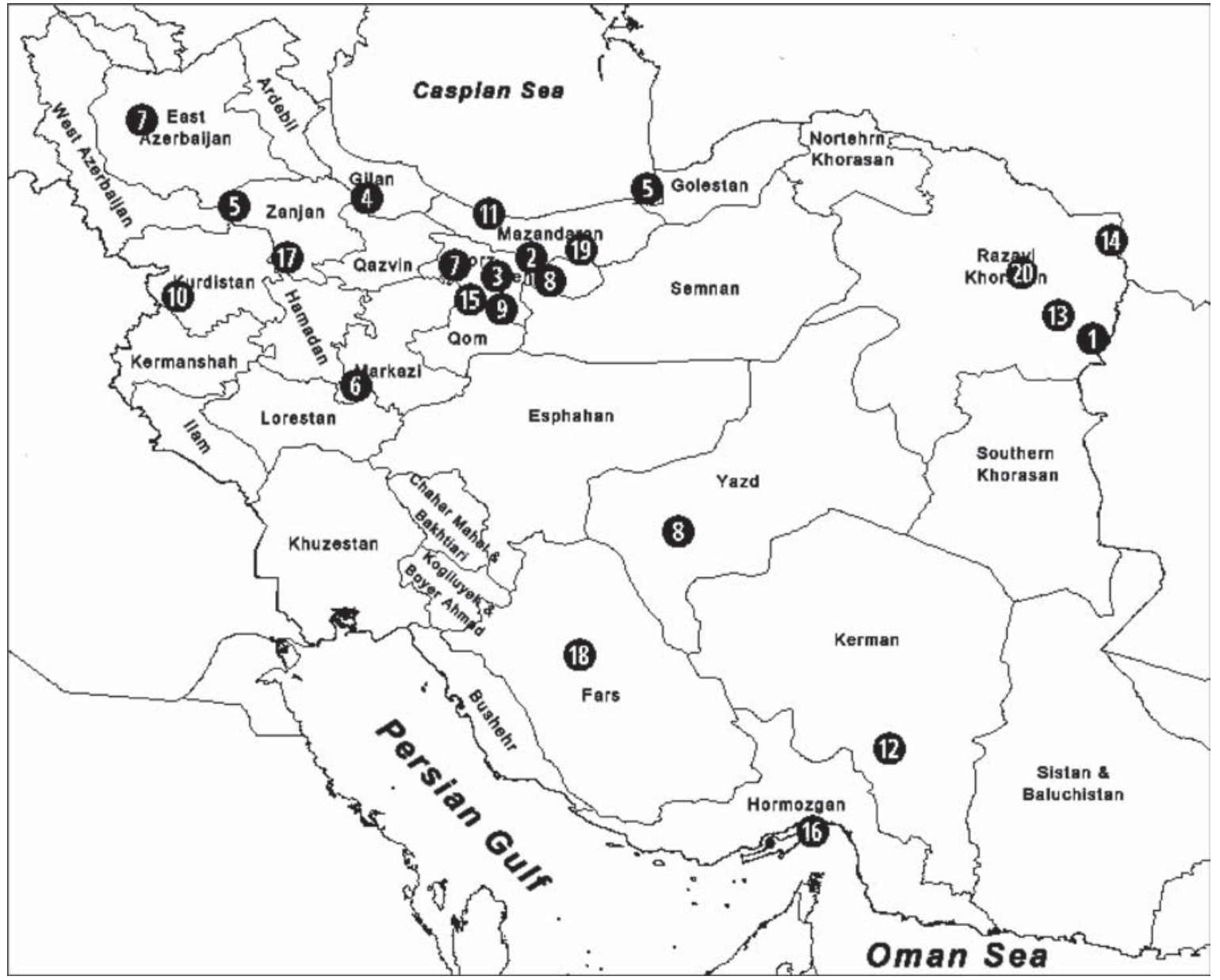

Map 1. Collecting localities for: (1) Benoitia lepida, Paracedicus gennadii, Evippa caucasica, Eusparassus kronebergi, Steatoda ephippiata; (2) Agelescape gideoni, Drassodes lutescens, Nomisia aussereri; (3) Agelescape gideoni, Micaria formicaria, Euryopis quinqueguttata; Trachyzelotes jaxartensis; (4) Atypus muralis; (5) Clubiona genevensis; (6) Dictyna arundinacea; (7) Nomisia aussereri; (8) Poecilochroa senilis; (9) Sidydrassus shumakovi; (10) Hersiliola turcica; (11) Ero aphana, Trachyzelotes pedestris; (12) Prochora lycosiformis; (13) Xysticus cf. kaznakovi, Xysticus turkmenicus; (14) Trachyzelotes jaxartensis, Eusparassus oculatus; (15) Hersiliola simoni; (16) Oecobius putus, Enoplognatha turkestanica; (17) Plexippoides gestroi; (18) Robertus arundineti, Firmicus dewitzi, Clubiona genevensis; (19) Titanoeca schineri; (20) Steatoda ephippiata.

Карта 1. Места сборов: (1) Benoitia lepida, Paracedicus gennadii, Evippa caucasica, Eusparassus kronebergi, Steatoda ephippiata; (2) Agelescape gideoni, Drassodes lutescens, Nomisia aussereri; (3) Agelescape gideoni, Micaria formicaria, Euryopis quinqueguttata; Trachyzelotes jaxartensis; (4) Atypus muralis; (5) Clubiona genevensis; (6) Dictyna arundinacea; (7) Nomisia aussereri; (8) Poecilochroa senilis; (9) Sidydrassus shumakovi; (10) Hersiliola turcica; (11) Ero aphana, Trachyzelotes pedestris; (12) Prochora lycosiformis; (13) Xysticus cf. kaznakovi, Xysticus turkmenicus; (14) Trachyzelotes jaxartensis, Eusparassus oculatus; (15) Hersiliola simoni; (16) Oecobius putus, Enoplognatha turkestanica; (17) Plexippoides gestroi; (18) Robertus arundineti, Firmicus dewitzi, Clubiona genevensis; (19) Titanoeca schineri; (20) Steatoda ephippiata.

mens were photographed by means of an Olympus DP71 camera attached to an Olympus SZH-10 stereomicroscope at the Ferdowsi University of Mashhad (Iran). The specimens of Trachelas minor were photographed by means of an Olympus Camedia E-520 camera attached to an Olympus SZX16 stereomicroscope at the Zoological Museum of University of Turku (Finland), and the specimens of Agelescape gideoni were photographed by means of a Leica MC170 HD camera attached to a Leica M165 C stereomicroscope at the Naturhistorisches Museum Basel (Switzerland). If not otherwise stated, widespread species were identified by means of the well-known manual and database by Nentwig et al. [2015].
Species distribution is based on the information provided in several databases and catalogues: viz., Mikhailov [2013], Helsdingen [2014], WSC [2015] and other sources. In order to recognize a new record status of the treated species, all records were checked against the checklist by Zamani et al. [2016].

The depositories of the studied specimens are as follows: MHNG — Muséum d'histoire naturelle de la Ville de Genève (curator: Peter Schwendinger); NMB Naturhistorisches Museum Basel (curator: Ambros Hänggi); NNHM — National Museum of Natural History \& Genetic Resources, Iran (curator: Alireza Naderi); ZMFUM - Zoological Museum of Ferdowsi University of Mashhad (curator: Omid Mirshamsi); ZMMU - 


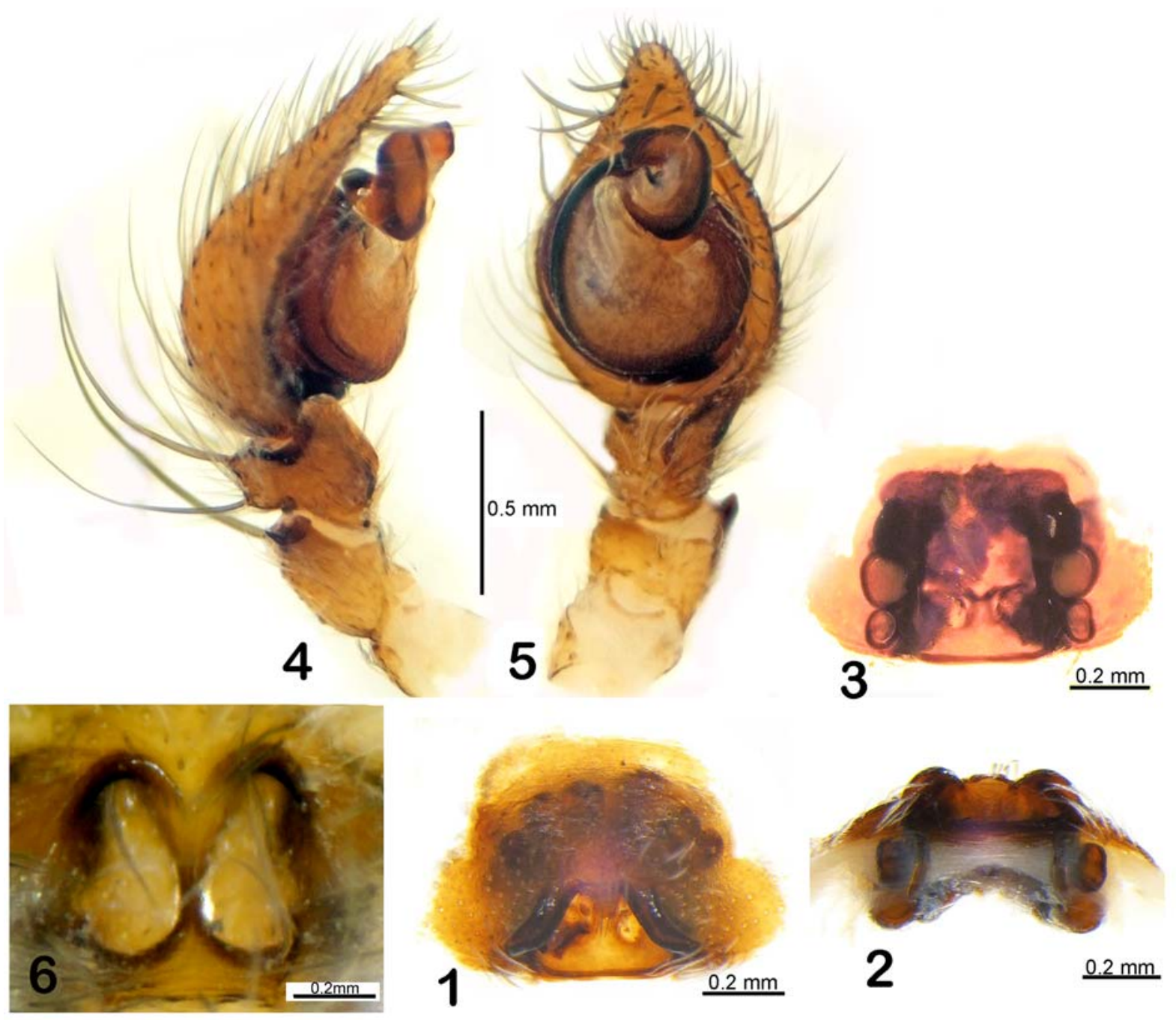

Figs 1-6. Copulatory organs of Agelescape gideoni (1-3) and Benoitia lepida (4-6): 1 - male palp, lateral view; 2 - ditto, ventral view; 3,4 - epigyne, ventral view; 5 - ditto, caudal view; 6 - vulva, dorsal view.

Рис. 1-6. Копулятивные органы Agelescape gideoni (1-3) и Benoitia lepida (4-6): 1 - пальпа самца, сбоку; 2 — то же, снизу; 3, 4 - эпигина, снизу; 5 - то же, сзади; 6 - вульва, сверху.

Zoological Museum of the Moscow State University (curator: Kirill Mikhailov); ZUTC — Zoological Museum, University of Tehran (curator: Alireza Sari).

\section{Results}

Family Agelenidae

Agelescape Levy, 1996

COMMENTS. Currently, the genus consists of seven valid species. Agelescape livida (Simon, 1875), the generotype, is the only species with a relatively wide distribution (the Mediterranean). The other six seem to be more geographically restricted from the east Mediterranean region to Azerbaijan [Guseinov et al., 2005]. Three of them remain known from one sex only $(A$. caucasica Guseinov, Marusik et Koponen, 2005 and
A. talyshica Guseinov, Marusik et Koponen, 2005 from the females; and A. levyi Guseinov, Marusik et Koponen, 2005 from the male). So far, there have been no records of Agelescape from Iran, which is obviously due to the lack of data. Finally, Guseinov et al. [2005: 156] mentioned that they observed "several undescribed species from adjacent Iran" which have not been described yet.

Agelescape gideoni Levi, 1996

Figs 1-3.

Agelescape gideoni Levy, 1996: 91, figs 20-23 (O'O).

MATERIAL. Tehran Prov: 2 of (NMB: AB1344), Tochal Mts $\left(35^{\circ} 49^{\prime} 40^{\prime \prime} \mathrm{N}, 51^{\circ} 24^{\prime} 15^{\prime \prime} \mathrm{E}\right)$, March 2013, A. Zamani. - Mazandaran Prov:: 1 ㅇ (ZUTC), Damavand, Polur $\left(35^{\circ} 50^{\prime} 55^{\prime \prime} \mathrm{N}\right.$, $52^{\circ} 03^{\prime} 01^{\prime \prime}$ E), October 2015, A. Zamani.

COMMENTS. These specimens can easily be recognized as Agelescape thanks to the characteristic epi- 


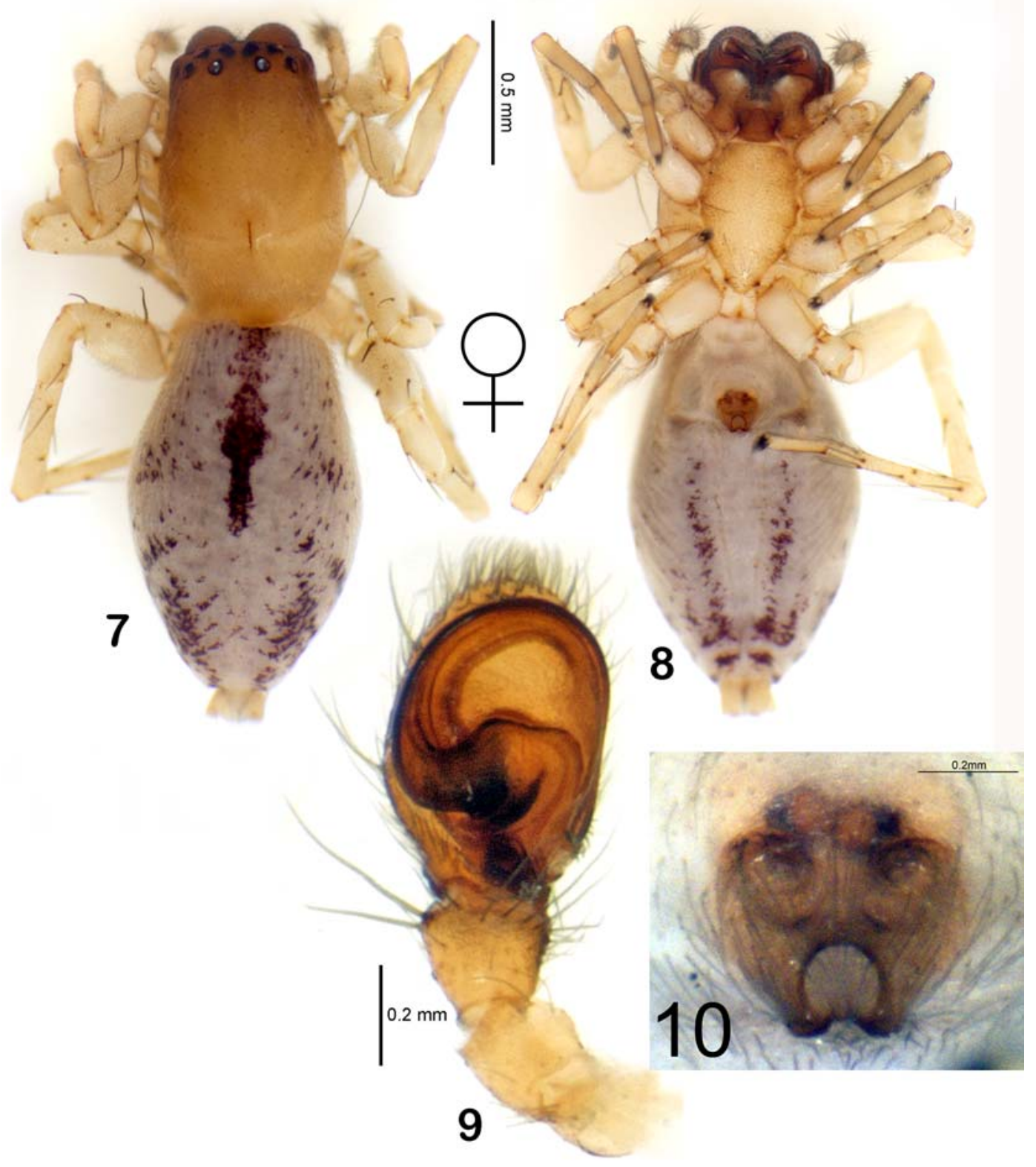

Figs 7-10. Copulatory organs and habitus of Clubiona genevensis: 7 - female habitus, dorsal view; 8 - ditto, ventral view; $9-$ male palp, ventral view; 10 - epigyne, ventral view.

Рис. 7-10. Копулятивные органы и габитус Clubiona genevensis: 7 -габитус самки, сверху; 8 - то же, снизу; 9 - пальпа самца, снизу; 10 - эпигина, снизу.

gynal depression partly covered by a membranous scape extending from the anterior rim [Levy, 1996]. Based on Levy's [1996] descriptions and drawings, the specimens are most similar to $A$. gideoni. Based on the descriptions by Guseinov et al. [2005], the epigyne and vulva of our specimens show a clear similarity to those of $A$. dunini Guseinov, Marusik et Koponen, 2005. As shown by Guseinov et al. [2005: fig. 8], the arrangement of female genital sclerites seems to be highly variable in A. dunini (a left-right asymmetry). Given this variability, $A$. dunini differs from $A$. gideoni only in the somewhat bifurcated scape, the anchor-shaped foveal plate and body size [Guseinov et al., 2005:
158]. Unfortunately, we do not have a male in our collection. But even with the male at hand we would expect to encounter problems given the available figures of $A$. gideoni [Levy, 1996: 91, figs 20-21] and $A$. dunini from [Guseinov et al., 2005: 155, figs 1-2], which are rather alike. Besides, in the diagnosis of $A$. dunini, the older species name $A$. gideoni was not mentioned at all. The clarification of the validity of $A$. dunini is outside the scope of the present paper, whereas we prefer to refer the studied specimens to as $A$. gideoni. Given the currently known distribution of the species ranging from Israel to Turkey, our findings lie at its easternmost limits. 


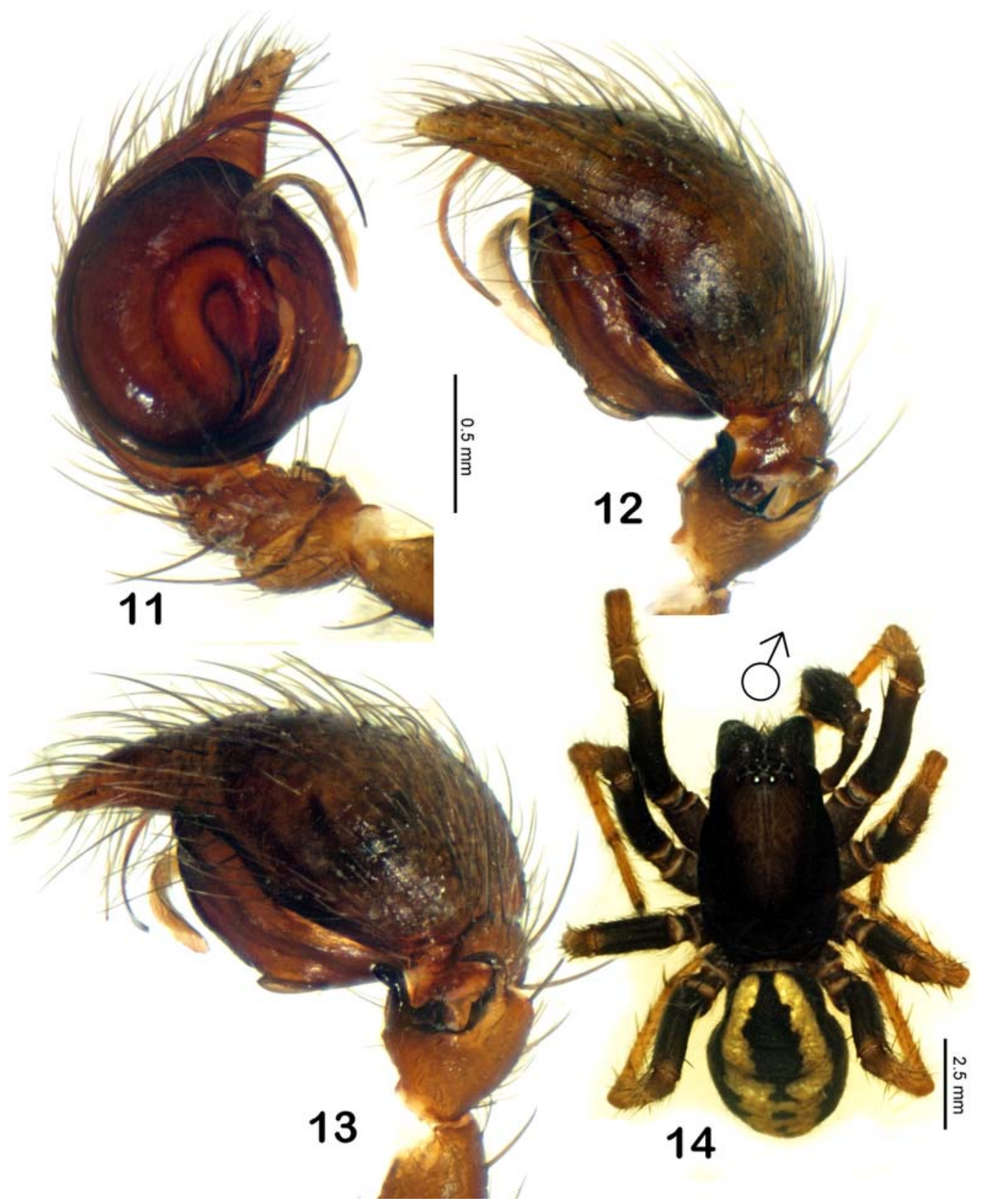

Figs 11-14. Male palp and habitus of Paracedicus gennadii: 11 - palp, ventral view; $12-13$ - ditto, lateral view; 14 - habitus, dorsal view.

Рис. 11-14. Пальпа и габитус самца Paracedicus gennadii: 11 — palp, снизу; 12-13 — то же, сбоку; 14 — габитус, сверху.

\section{Benoitia Lehtinen, 1967}

COMMENTS. Currently, the genus consists of nine valid species, which are distributed in Spain, Africa, Cyprus, Middle East and China (Gansu, Xinjiang).

Benoitia lepida (O. Pickard-Cambridge, 1876) Figs 4-6.

Benoitia lepida: Levy, 1996: 95, figs 36-39 (0'+9).
MATERIAL. Khorasan-e Razavi Prov: $20^{7} 0^{7}, 3$ OO (ZMFUM), Taybad, Hossein Abad, September 2014, P. Rashidi.

COMMENTS. This species has been recorded from North Africa, Cyprus, Israel, Yemen, Saudi Arabia, Kuwait, Turkey, Egypt and Libya [Bolzern, 2015]. Its previous record from Fars Province by Brignoli [1977] was considered doubtful by Zamani et al. [2016]. Based to the illustrations of the epigyne presented by Levy [1996], our specimens represent the first verified record of this species from Iran, and the easternmost record of the known species' range. 


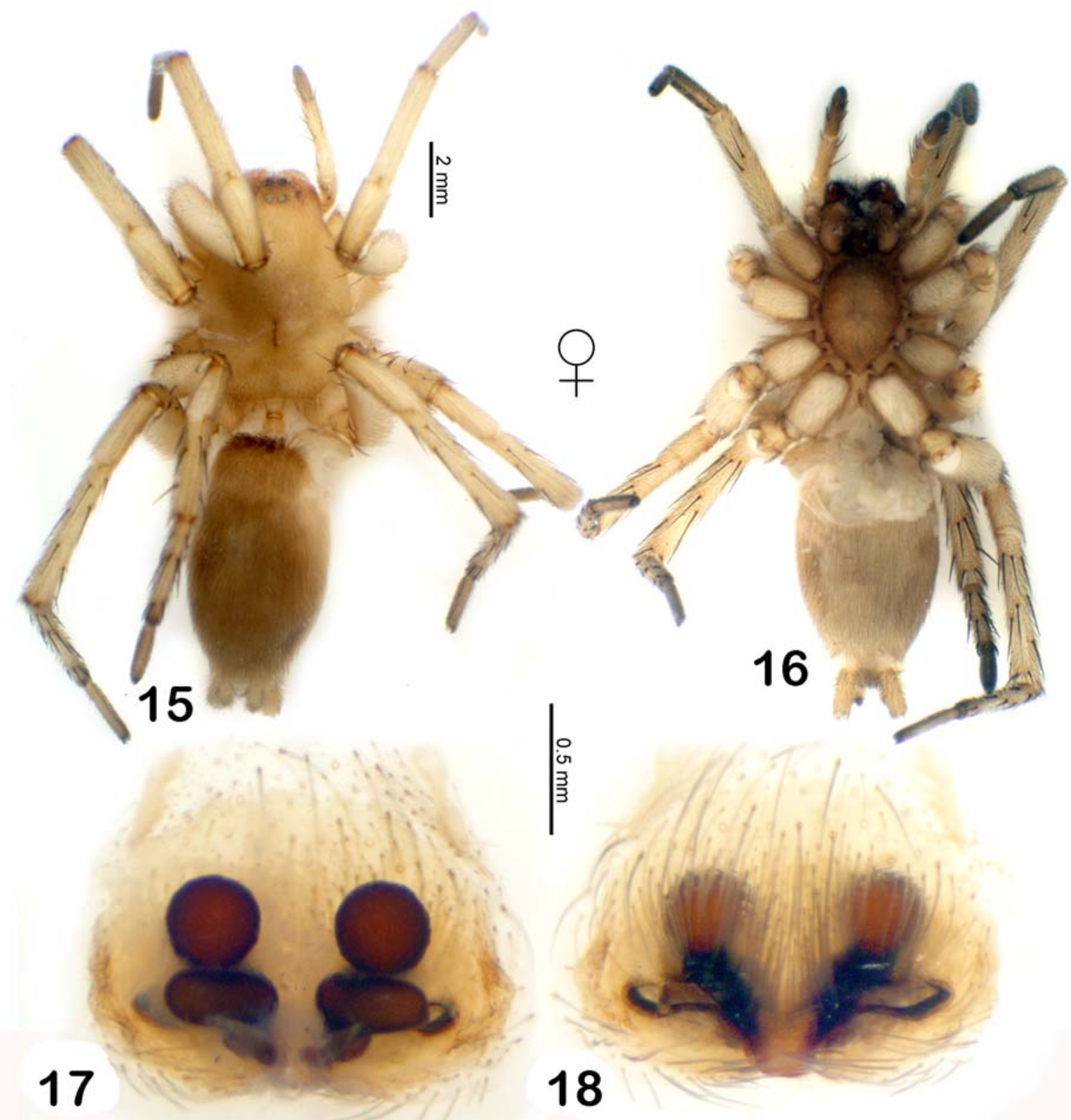

Figs 15-18. Epigyne and female habitus of Sidydrassus shumakovi: 15 - habitus, dorsal view; 16 - ditto, ventral view; 17 - vulva; 18 - epigyne, ventral view.

Рис. 15-18. Эпигина и габитус самки Sidydrassus shumakovi: 15 — габитус, сверху; 16 - то же, снизу; 17 - вульва; 18 эпигина, снизу.

\section{Family Atypidae}

Atypus muralis Bertkau, 1890

Atypus muralis: Schwendinger, 1990: 358, figs 16, 30, 32 ( + ). MATERIAL. Gilan Prov.: 1 \% (MHNG), road from Masuleh $\left(37^{\circ} 11^{\prime} \mathrm{N}, 49^{\circ} 07^{\prime} \mathrm{E}\right), 1000 \mathrm{~m}$ a.s.1., April 1973, A. Senglet.

COMMENTS. This species is distributed from Central Europe to Turkmenistan [WSC, 2015].

Family Clubionidae

Clubiona genevensis L. Koch, 1866

Figs 7-10.
MATERIAL. Golestan Prov.: $10^{7}$ (ZMFUM), Miankaleh, Ashuradeh Island $\left(36^{\circ} 50^{\prime} \mathrm{N}, 53^{\circ} 51^{\prime} \mathrm{E}\right)$, May 2015 , A. Zamani. Zanjan Prov.: 1 ( (ZMFUM), Mahneshan, Dandi Vil. (36 $36^{\circ} 40^{\prime \prime} \mathrm{N}$, $\left.47^{\circ} 40^{\prime} 21^{\prime \prime} \mathrm{E}\right)$, September 2014, A. Mahmoudi. - Fars Prov.: 5 $0^{7} \sigma^{7}, 6$ 오 (ZMMU), Shiraz, Quran Gate $\left(29^{\circ} 38^{\prime} \mathrm{N}, 52^{\circ} 33^{\prime} \mathrm{E}\right)$, leaf and pine needle litter in a small park, December 2013, Yu.M. Marusik.

COMMENTS. This species has a west-Palaearctic distribution, eastward to Xinjiang (China) [WSC, 2015].

Family Cybaeidae

Paracedicus Fet, 1993

COMMENTS. Currently, the genus consists of five valid species distributed in Israel, Azerbaijan 

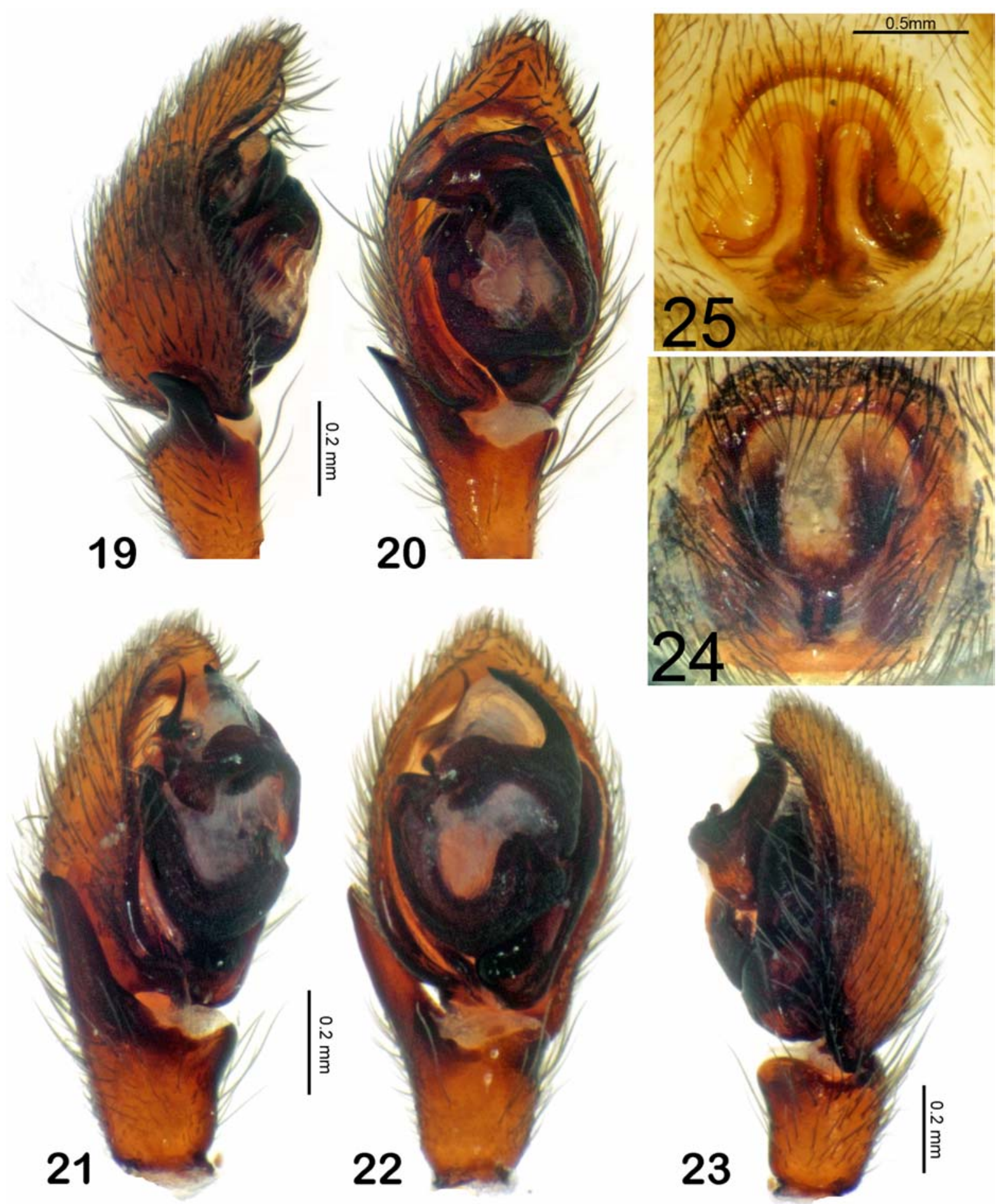

Figs 19-25. Copulatory organs of Trachyzelotes jaxartensis (19-20, 25) and T. pedestris (21-24): 19 - male palp, lateral view; 20 ditto, ventral view; 21, 23- male palp, lateral; 22 - ditto, ventral view; 24, 25 - epigyne, ventral view.

Рис. 19-25. Копулятивные органы Trachyzelotes jaxartensis (19-20, 25) и T. pedestris (21-24): 19 — пальпа самца, сбоку; 20 то же, снизу; 21, 23 - пальпа самца, сбоку; 22 - то же, снизу; 24, 25 - эпигина, снизу.

and Turkmenistan. This is the first record for Iran.

Paracedicus gennadii (Fet, 1993)

Figs 11-14.
Cedicus gennadii Fet, 1993: 71, figs 2a-e ( $\sigma^{7}$ ).

MATERIAL. Khorasan-e Razavi Prov.: $1 \mathrm{O}^{7}$ (ZMFUM), Taybad, Kal-Sang $\left(4^{\circ} 44^{\prime} 24^{\prime \prime} \mathrm{N}, 60^{\circ} 46^{\prime} 32^{\prime \prime} \mathrm{E}\right)$, pit-fall trap, November 2014, P. Rashidi.

COMMENTS. Hitherto, the species was known from Turkmenistan [WSC, 2015]. Our record lies in 


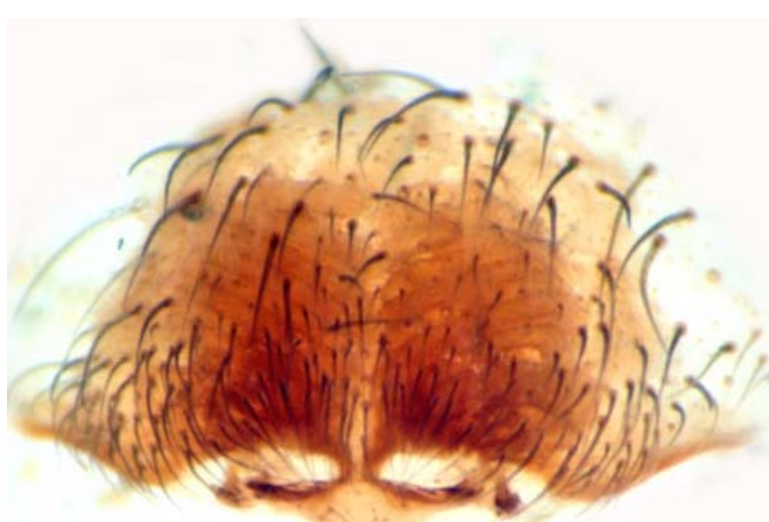

26

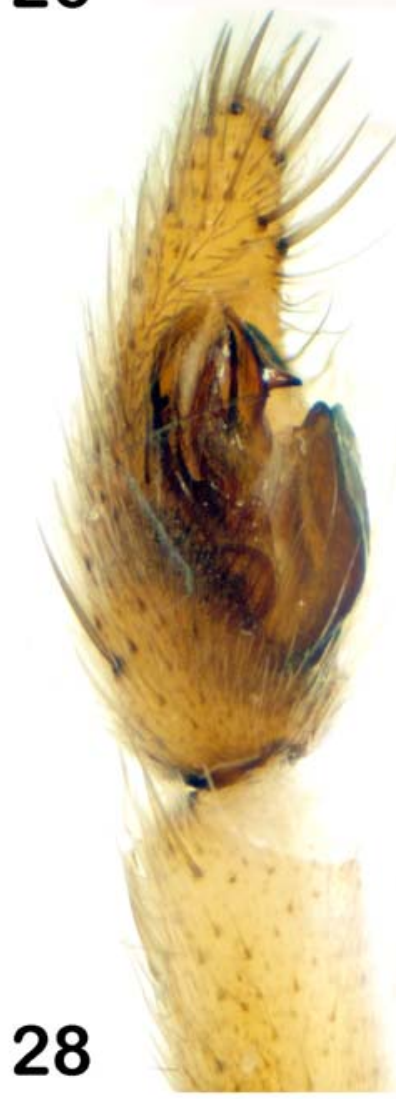

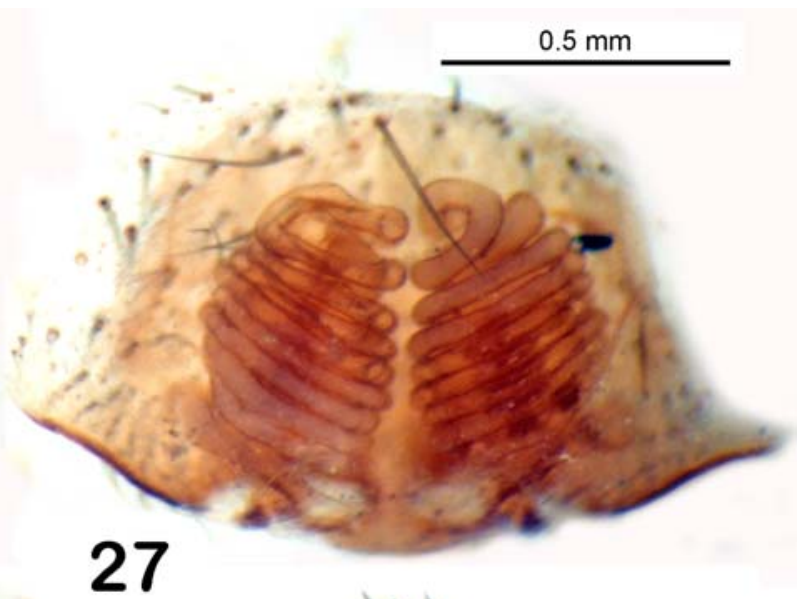
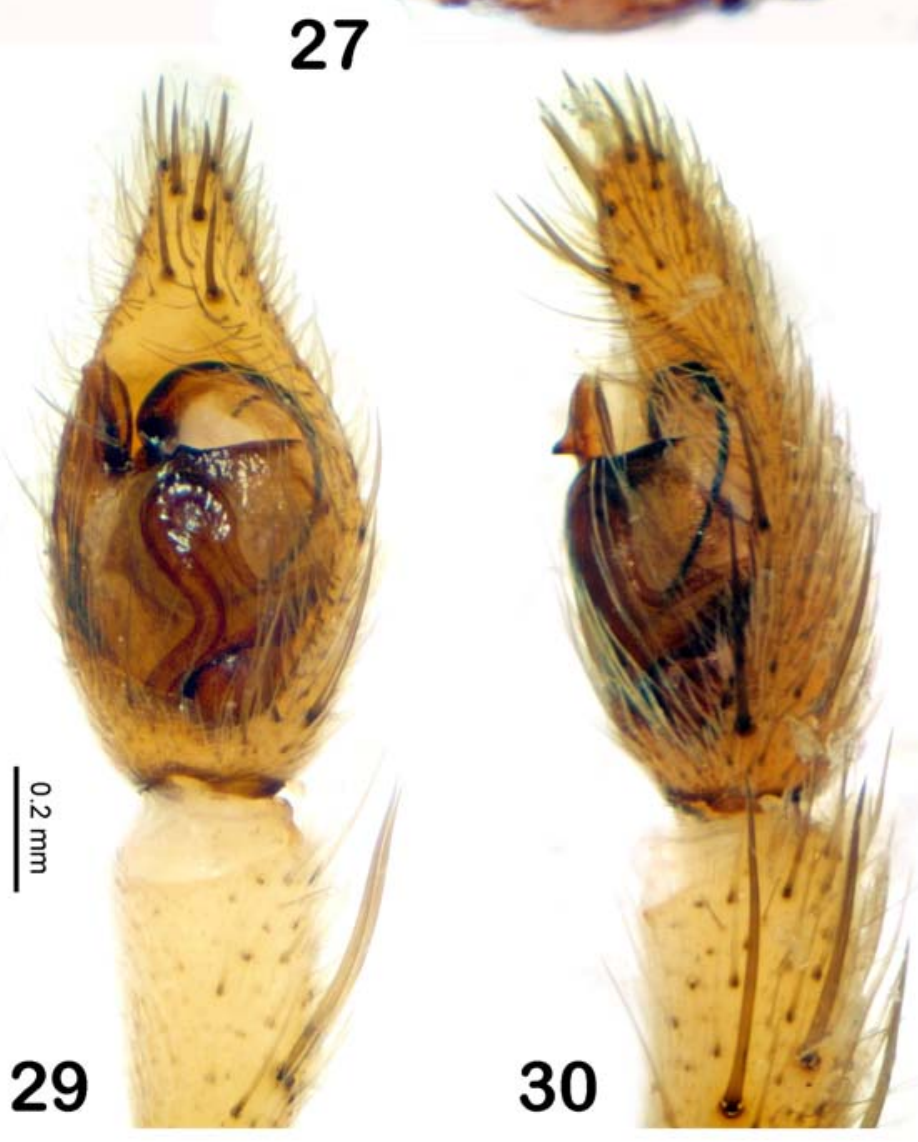

Figs 26-30. Copulatory organs of Hersiliola turcica (26-27) and Evippa caucasica (28-30): 26 - epigyne, 27 — vulva; 28, 30 male palp, lateral view; 29 - ditto, ventral view.

Рис. 26-30. Копулятивные органы Hersiliola turcica (26-27) и Evippa caucasica (28-30): 26 — эпигина, 27 - вульва; 28,30 пальпа самца, сбоку; 29 - то же, снизу.

the southernmost limit of the species' known range. Both genus and species are new to Iran.

Family Dictynidae

\section{Dictyna arundinacea (Linnaeus, 1758)}

MATERIAL. Markazi Prov.: 1 (ZUTC), Shazand (335ㄴㅅN, $49^{\circ} 18^{\prime} \mathrm{E}$ ), September 2015, A. Zamani.

COMMENTS. This species has a Holarctic distribution [WSC, 2015]. Both genus and species are new to Iran.
Family Gnaphosidae

Drassodes lutescens (C.L. Koch, 1839)

MATERIAL. Mazandaran Prov: $10^{7}$ (ZUTC), Damavand, Polur $\left(35^{\circ} 50^{\prime} 55^{\prime \prime} \mathrm{N}, 52^{\circ} 03^{\prime} 01^{\prime \prime} \mathrm{E}\right)$, October 2015, A. Zamani.

COMMENTS. This species is distributed from the Mediterranean to Pakistan [WSC, 2015].

Micaria formicaria (Sundevall, 1831)

MATERIAL. Tehran Prov.: 1 (ZUTC), Jajrood, Latian Forest Park $\left(35^{\circ} 47^{\prime} \mathrm{N}, 51^{\circ} 40^{\prime} \mathrm{E}\right)$, March 2015 , A. Zamani. 
COMMENTS. This species has a Palaearctic distribution [WSC, 2015].

\section{Nomisia aussereri (C.L. Koch, 1872)}

MATERIAL. East Azarbayjan Prov: 1 o, 6 우 (NNHM), Tabriz to Marand, April 1975, Morovatti. - Alborz Prov.: 1 o (ZUTC) Taleghan, Taleghan Lake $\left(36^{\circ} 11^{\prime} 24^{\prime \prime} \mathrm{N}, 50^{\circ} 37^{\prime} 48^{\prime \prime} \mathrm{E}\right)$, August 2013, A. Zamani. - Mazandaran Prov.: 1 (ZUTC), Damavand, Polur $\left(35^{\circ} 50^{\prime} 55^{\prime \prime} \mathrm{N}, 52^{\circ} 03^{\prime} 01^{\prime \prime} \mathrm{E}\right)$, October 2015 , A. Zamani.

COMMENTS. This species has a west-Palaearctic distribution [WSC, 2015], eastward going to Yenisei River (Russia).

Poecilochroa senilis (O. Pickard-Cambridge, 1872)

MATERIAL. Tehran Prov.: 1 (ZUTC), Damavand, road to Tar Lake $\left(35^{\circ} 43^{\prime} \mathrm{N}, 52^{\circ} 13^{\prime} \mathrm{E}\right)$, July 2015 , A. Zamani. - Yazd Prov.: 1 \& (ZUTC) Ashkzar, Sharaf Abad, October 1998, Ghayoomi.

COMMENTS. This species is distributed from Corsica to Turkmenistan [WSC, 2015]. Both genus and species are new to Iran. Our record from Yazd Prov. seems southernmost in the whole known range.

\section{Sidydrassus Esyunin et Tuneva, 2002}

COMMENTS. Currently, the genus consists of three valid species distributed in Kazakhstan, Russia and China. The genus is recorded from Iran and the entire Middle East for the first time.

\section{Sidydrassus shumakovi (Spassky, 1934)} Figs 15-18.

Sidydrassus shumakovi: Esyunin, Tuneva, 2002: 177, figs 48$57\left(\sigma^{\top}+\right)$.

MATERIAL. Tehran Prov.: 1 (ZMFUM), Rey County, Eshgh Abad Wetland $\left(35^{\circ} 27^{\prime} 51^{\prime \prime} \mathrm{N}, 51^{\circ} 31^{\prime} 06^{\prime \prime} \mathrm{E}\right)$, October 2014 , A. Zamani.

COMMENTS. The species was hitherto known from south-eastern Russia and Kazakhstan [WSC, 2015]. Our specimen represents the southernmost record of both genus and species. Genus and species are new to Iran (and the Middle East).

Trachyzelotes jaxartensis (Kroneberg, 1875) Figs 19-20, 25.

MATERIAL. Alborz Prov.: 1 ( (ZUTC), Karaj, Azimieh, Kuhe-Noor $\left(35^{\circ} 50^{\prime} \mathrm{N}, 51^{\circ} 00^{\prime} \mathrm{E}\right)$, March 2015, A. Zamani. - Khorasan-e Razavi Prov.: 1 \& (ZMFUM), Sarakhs, Abgarm $\left(36^{\circ} 24^{\prime} 48^{\prime \prime} \mathrm{N}, 60^{\circ} 04^{\prime} 20^{\prime \prime} \mathrm{E}\right)$, no date, Z. Nikmagham.

COMMENTS. This species has a Holarctic distribution, but in Eurasia it occurs only in the West Palaearctic [WSC, 2015].

Trachyzelotes pedestris (C. L. Koch, 1837)

Figs 21-24.

MATERIAL. Mazandaran Prov.: 3 O $^{7} \mathrm{O}^{7}, 1+$ (ZMFUM), c. 20 $\mathrm{km} \mathrm{N}$ of Chalus, May 2015, D. Kasatkin.

COMMENTS. This species is distributed from Europe to Azerbaijan [WSC, 2015] and Iran [present data]. Our record seems to lie in the easternmost limit of the known species' range.

Family Hersiliidae

Hersiliola simoni (O. Pickard-Cambridge, 1872)

Hersiliola simoni: Levy, 2003: 25, figs 47-56 (( $\left.0^{7}+\right)$.

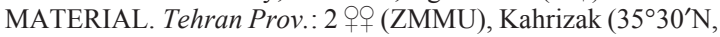
$51^{\circ} 21^{\prime} \mathrm{E}$ ), May 2015, A. Zamani.

COMMENTS. This species was hitherto known from the Mediterranean and Nigeria [WSC, 2015]; the latter record is likely to be based on a misidentification. The Iranian finding lies in the easternmost limit of the known species' range.

Hersiliola turcica Marusik, Kunt et Ya mur, 2010 Figs 26-27.

Hersiliola turcica Marusik, Kunt et Ya mur, 2010: 28, figs 1$13\left(\sigma^{\top}+\right)$.

MATERIAL. Kurdistan Prov.: 1 q (ZMFUM), Marivan $\left(35^{\circ} 20^{\prime} 48^{\prime \prime} \mathrm{N}, 46^{\circ} 9^{\prime} 54^{\prime \prime} \mathrm{E}\right)$, August 2015, A. Zamani.

COMMENTS. This species was hitherto known from Turkey only [WSC, 2015]; our finding represents the southeasternmost record of the known species' range.

Family Lycosidae

Evippa caucasica Marusik, Guseinov et Koponen, 2003 Figs 28-30.

Evippa caucasica Marusik, Guseinov et Koponen, 2003: 52, figs 4-6 $\left(O^{7}\right)$.

MATERIAL. Khorasan-e Razavi Prov: $2 \sigma^{7} \sigma^{7}$ (ZMFUM), Taybad, Mohammad Abad Qods, April 2014, P. Rashidi.

COMMENTS. To date, this species has been described and known from Azerbaijan only [WSC, 2015]. Thus, our record represents the easternmost limit of its distribution.

Family Mimetidae

Ero aphana (Walckenaer, 1802)

MATERIAL. Mazandaran Prov.: $1 \sigma^{\top}, 2$ 90 (ZMMU), Nashtarood-Khoshkadaran $\left(36^{\circ} 45^{\prime} 00.0^{\prime \prime} \mathrm{N}, 51^{\circ} 01^{\prime} 58.8^{\prime \prime} \mathrm{E}\right)$, June 2000 , Yu.M. Marusik.

COMMENTS. This species has a west-Palaearctic distribution [WSC, 2015].

Family Miturgidae

Prochora Simon, 1886

COMMENTS. Currently, the genus consists of two valid species, of which one is known from Sicily and Israel, and another from eastern China, Korea and Japan [WSC, 2015]. This is the first record of the genus from Iran. 

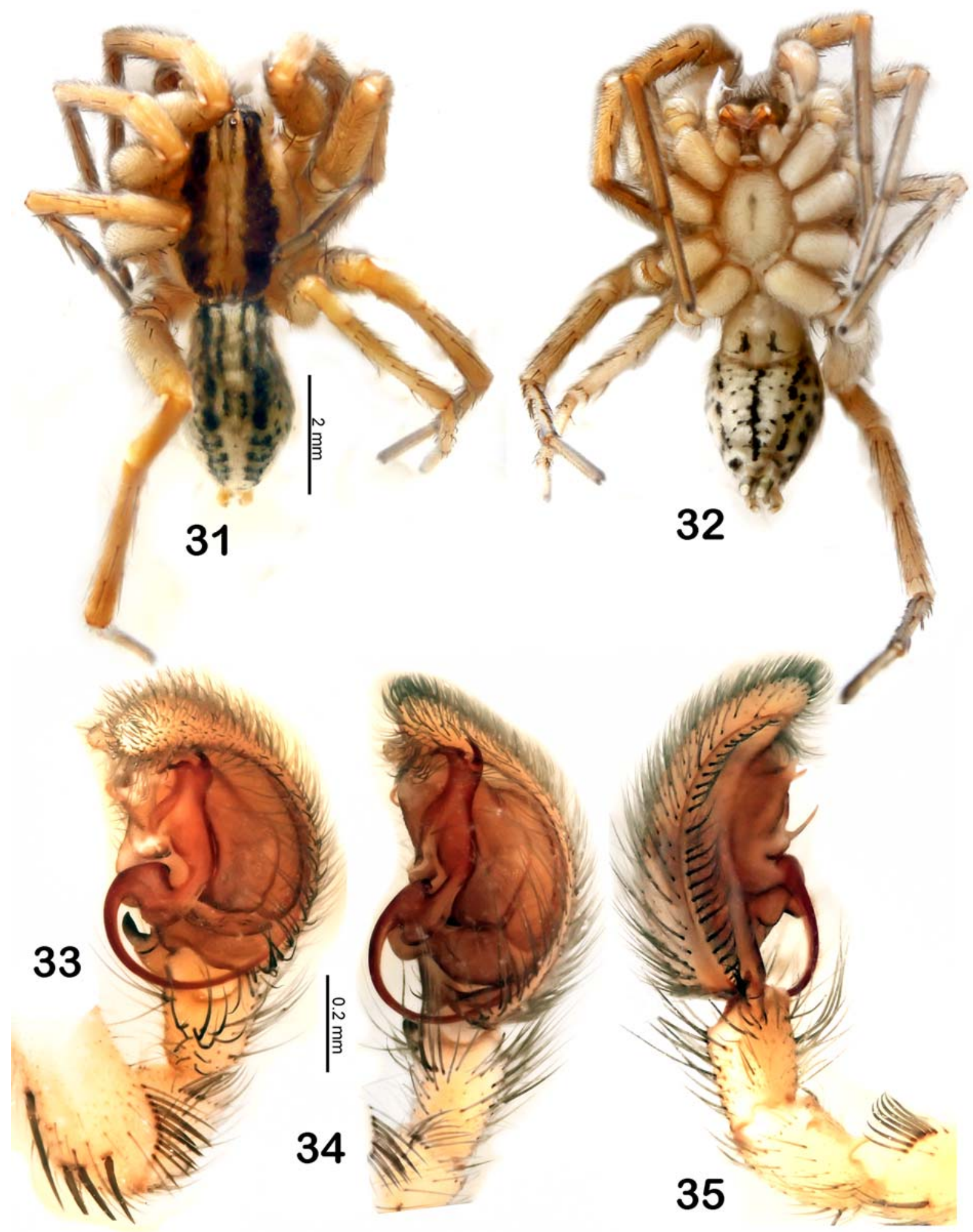

32

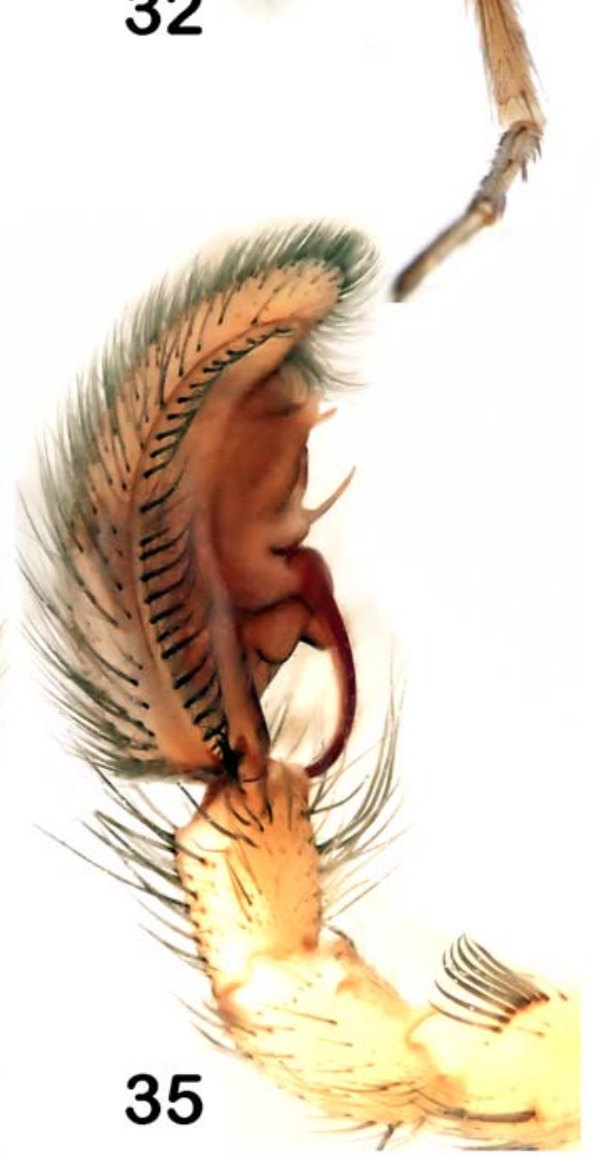

Figs 31-35. Male copulatory organ and habitus of Prochora lycosiformis: 31 — habitus, dorsal view; 32 - ditto, ventral view; 33 palp, ventral view; 34,35 - ditto, lateral view.

Рис. 31-35. Пальпа и габитсу самца Prochora lycosiformis: 31 - габитус, сверху; 32 - то же, снизу; 33 - пальпа, снизу; 34, 35 - то же, сбоку. 


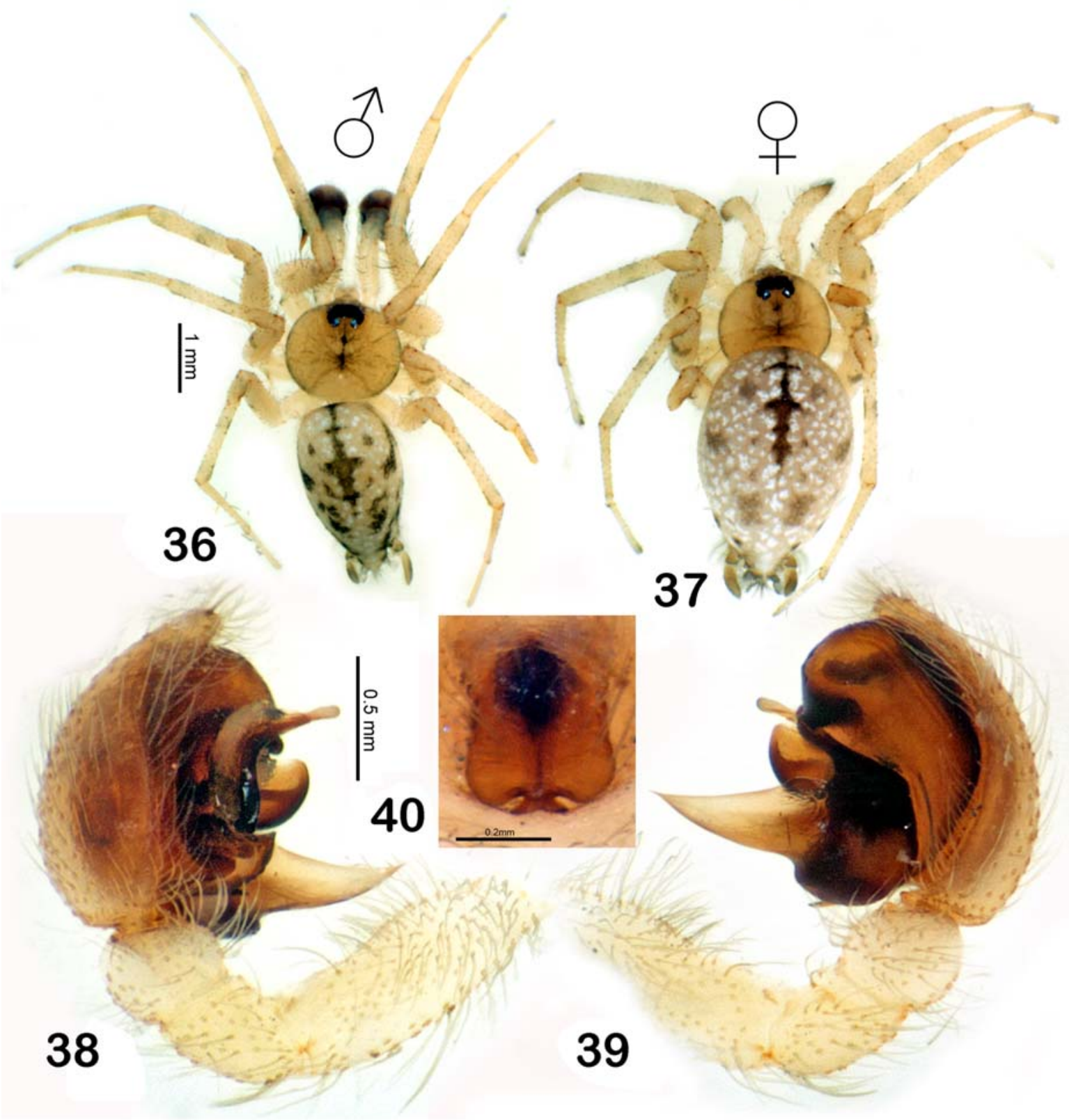

Figs 36-40. Copulatory organs and habitus of Oecobius putus: 36 - male habitus, dorsal view; 37 - female habitus, dorsal view: 38 , 39 - male palp, lateral view; 40 - epigyne, ventral view.

Рис. 36-40. Копулятивные органы и габитус самца Oecobius putus: 36 - габитус, сверху; 37 - габитус самки, сверху: 38, 39 - пальпа самца, сбоку; 40 - эпигина, снизу.

Prochora lycosiformis (O. Pickard-Cambridge, 1872) Figs 31-35.

MATERIAL. Kerman Prov.: $1 \mathrm{O}^{\top}$ (ZMFUM), Jiroft, May 2011, O. Mirshamsi.

COMMENTS. Hitherto, this species was recorded from Sicily and Israel [WSC, 2015]. The record from Kerman Province represents the easternmost limit of the species' distribution. Family, genus and species records are new to Iran.
Family Oecobiidae

Oecobius putus O. Pickard-Cambridge, 1876 Figs 36-40.

Oecobius putus: Wunderlich, 1995: 596, figs 45-48 ( $0^{7}+$ ). MATERIAL. Hormozgan Prov.: $1 \sigma^{7}, 2$ +क (ZMFUM), Hormuz Island $\left(27^{\circ} 02^{\prime} 42^{\prime \prime} \mathrm{N}, 56^{\circ} 29^{\prime} 35^{\prime \prime} \mathrm{E}\right)$, January 2015 , A. Zamani.

COMMENTS. This species is distributed from Egypt to India [WSC, 2015]. 


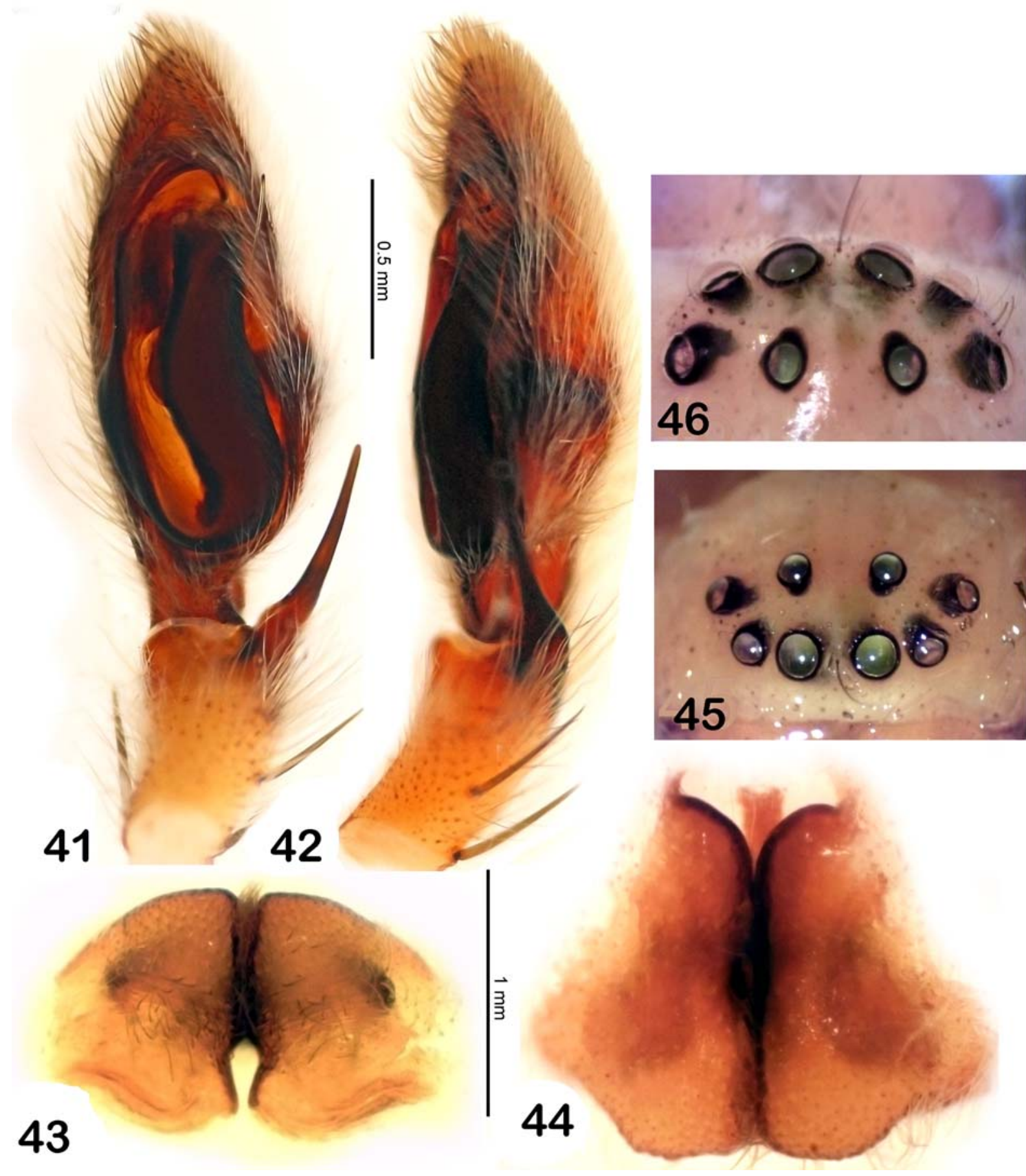

Figs 41-46. Eusparassus kronebergi (41-42) and Eu. oculatus (43-46): 41 - male palp, ventral view; 42 - ditto, lateral view; 43 epigyne, caudal view; 44 - ditto, ventral view; 45 - ocular area, front view; 46 - ditto, dorsal view.

Рис. 41-46. Eusparassus kronebergi (41-42) и Eu. oculatus (43-46): 41 - пальпа самца, снизу; 42 - то же, сбоку; 43 эпигина, сзади; 44 - то же, снизу; 45 - глазное поле, спереди; 46 - то же, сверху.

Family Salticidae

Plexippoides gestroi (Dalmas, 1920)

MATERIAL. Zanjan Prov.: $20^{7} 0^{7}$ (ZMFUM), Garm-ab (35 $\left.50^{\prime} \mathrm{N}, 48^{\circ} 9^{\prime} \mathrm{E}\right)$, September 2013, A. Zamani.
COMMENTS. This species is distributed in the Eastern Mediterranean [WSC, 2015]. Our record lies in the southernmost limit of the known species' range. 


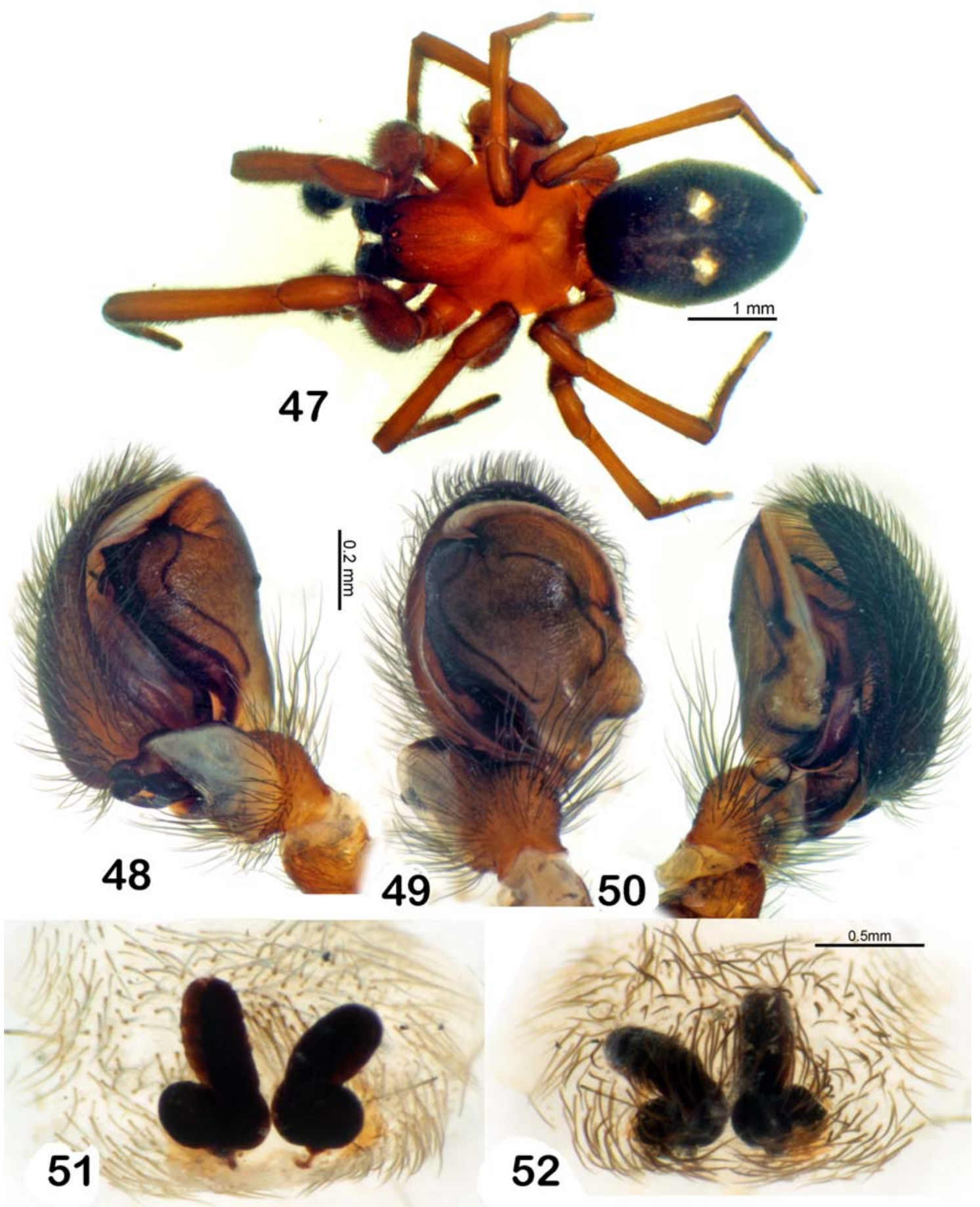

Figs 47-52. Copulatory organs and habitus of Titanoeca schineri: 47 - male habitus, dorsal view; 48, 50 — palp, lateral view; 49 ditto, ventral view; 51 - vulva; 52 - epigyne, ventral view.

Рис. 47-52. Копулятивные органы и габитус самца Titanoeca schineri: 47 - габитус, сверху; 48, 50 — пальпа, сбоку; 49 — то же, снизу; 51 - вульва; 52 - эпигина, снизу.

Family Sparassidae

Eusparassus kronebergi Denis, 1958

Figs 41-42. $\left(0^{\top}+\right)$.
MATERIAL. Khorasan-e Razavi Prov:: $20^{7} \sigma^{7}, 2$ 우, $10^{7}$ (sub.), 1 \& (sub.) (ZMFUM), Taybad, Kal-Sang (344ㄴ $24^{\prime \prime} \mathrm{N}$ $60^{\circ} 46^{\prime} 32^{\prime \prime}$ E), November 2014, P. Rashidi.

COMMENTS. This species has been recorded from Afghanistan and India [WSC, 2015]. Our record from Khorasan-e Razavi is the westernmost in the whole range. 


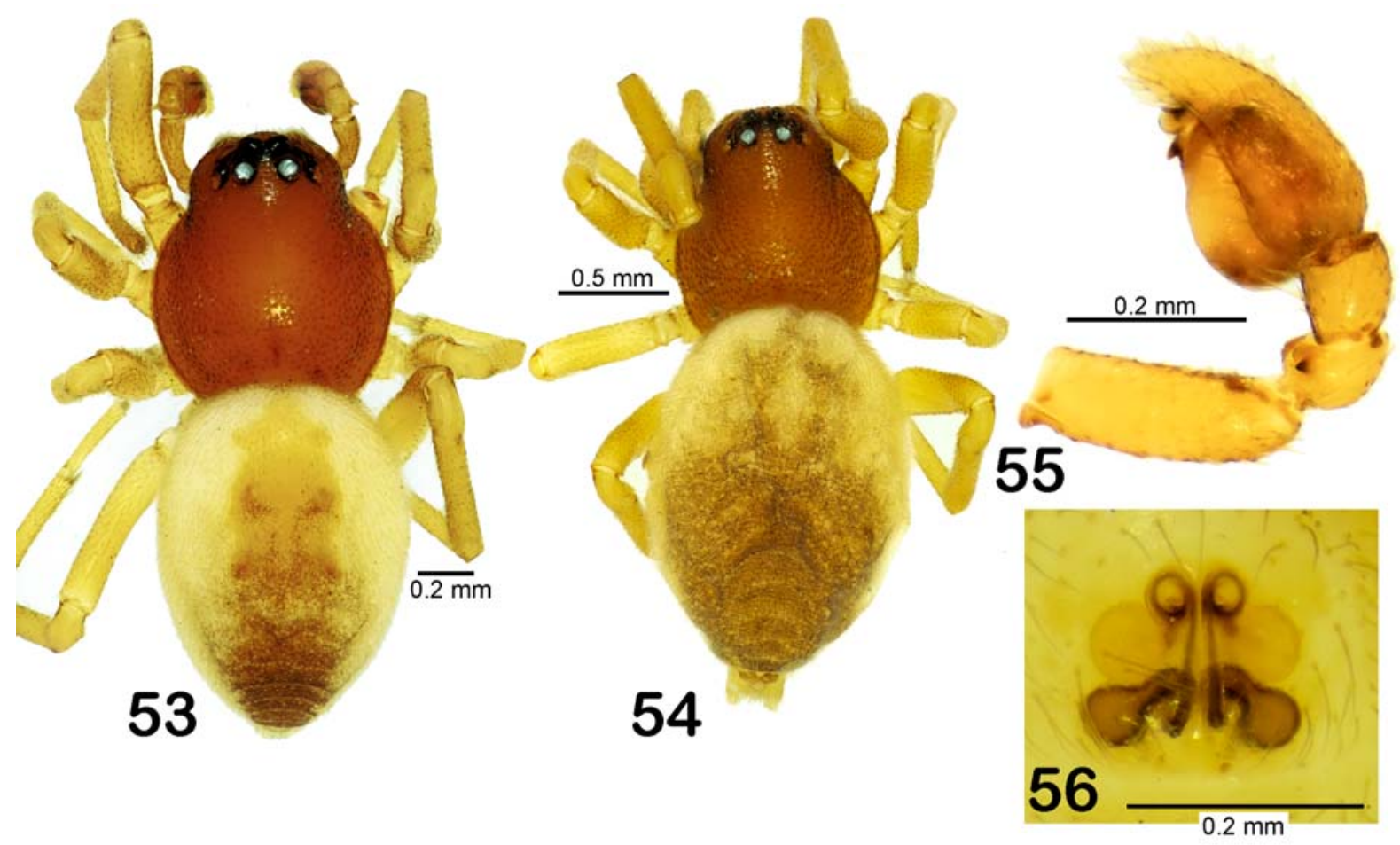

Figs 53-56. Copulatory organs and habitus of Trachelas minor: 53 - habitus of male, dorsal view; 54 - habitus of female, dorsal view; 55 - male palp, lateral view; 56 - epigyne, ventral view.

Рис. 53-56. Копулятивные органы и габитус Trachelas minor: 53 - габитус самца, сверху; 54 - габитус самки, сверху; 55 пальпа самца, сбоку; 56 - эпигина, снизу.

Eusparassus oculatus (Kroneberg, 1875)

Figs 43-46. $\mathrm{d}\left(\mathrm{O}^{\top}+\right)$.

Eusparassus oculatus: Moradmand, 2013: 69, figs 58e-f, 68c-

MATERIAL. Khorasan-e Razavi Prov.: 1 (ZMFUM), Sarakhs, Khaje Forest $\left(36^{\circ} 31^{\prime} 17^{\prime \prime} \mathrm{N}, 60^{\circ} 30^{\prime} 37^{\prime \prime} \mathrm{E}\right)$, June 2012, S. Javaheri.

COMMENTS. This species is easily distinguished from other congeners by its anterior median eyes largest [Moradmand, Jäger, 2012]. The presence of this species in Iran was expected, since it is widespread in Central Asia.

Family Theridiidae

Enoplognatha turkestanica Charitonov, 1946

Enoplognatha turkestanica Charitonov, 1946: 23, fig. 27 (†) MATERIAL. Hormozgan Prov.: $1 \sigma^{\gamma}, 2$ 우 (ZMMU), Hormuz Island $\left(27^{\circ} 02^{\prime} 42^{\prime \prime} \mathrm{N}, 56^{\circ} 29^{\prime} 35^{\prime \prime} \mathrm{E}\right)$, January 2014 , A. Zamani.

COMMENTS. The species was described on the basis of eight females from eastern Uzbekistan [Charitonov, 1946]. Although the original description was very brief and the illustration of endogyne was very schematic, the species has been reported from all Central Asian states [Mikhailov, 2013]. Our identification is based on the study of the syntype series of this species. Its redescription will be given in a separate paper. The finding from Hormuz Island is the southernmost record of this species.

\section{Euryopis quinqueguttata Thorell, 1875}

MATERIAL. Tehran Prov.: 1 (ZMMU), Plant-Protection-

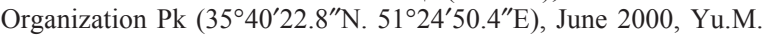
Marusik.

COMMENTS. This species is distributed in Europe and from Egypt to Turkmenistan [WSC, 2015].

Robertus arundineti (O. Pickard-Cambridge, 1871)

MATERIAL. Fars Prov: $1 \sigma^{7}$ (ZMMU), c. $50 \mathrm{~km}$ NNE of Shiraz, Bamou Res. $\left(29^{\circ} 45^{\prime} \mathrm{N}, 5^{\circ} 45^{\prime} \mathrm{E}\right)$, May 2000, Yu.M. Marusik.

COMMENTS. This species has a west-Palaearctic range [WSC, 2015].

Steatoda ephippiata (Thorell, 1875)

MATERIAL. Khorasan-e Razavi Prov.: 1 (ZMFUM), Mashhad, May 1997, O. Mirshamsi; 2 oᄋ (ZMFUM), Mashhad, June 2012, O. Mirshamsi; 1 \%, 3 oᄋ (ZMFUM), Taybad, Mohammad Abad Qods, April 2014, P. Rashidi; $1 \sigma^{\top}, 1$ q, 1 juv. (ZMFUM), Taybad, Kariz, July 2014, P. Rashidi; 1 フ , 2 우 (ZMFUM), Taybad, Kal-Sang, November 2014, P. Rashidi; 1 q (ZMFUM), Taybad, Haji Abad, November 2014, P. Rashidi.

COMMENTS. This species has been recorded from Algeria to Israel [WSC, 2015]. Our records from Khorasan-e Razavi are the easternmost in the whole range.

Family Thomisidae

Firmicus dewitzi Simon, 1899

Firmicus dewitzi: Levy, 1985: 33, figs 36-39 ( ( +$)$. 
MATERIAL. Fars Prov.: 1 (ZMMU), c. $50 \mathrm{~km} \mathrm{NE}$ of Shiraz, Bamou Res. $\left(29^{\circ} 45^{\prime} \mathrm{N}, 52^{\circ} 45^{\prime} \mathrm{E}\right)$, May 2000 , A. Khalil-Aria.

COMMENTS. This species was hitherto known from Israel and Egypt only [WSC, 2015]. The Iranian record lies in the easternmost limit of the known species' range. Both genus and species are new to Iran.

\section{Xysticus turkmenicus Marusik et Logunov, 1995}

Xysticus turkmenicus Marusik et Logunov, 1995: 148, figs 3033 (०์+

MATERIAL. Khorasan-e Razavi Prov.: 3 O $^{7} \mathrm{O}^{7}$ (ZMFUM), $36^{\circ} 14^{\prime} 45^{\prime \prime} \mathrm{N}, 59^{\circ} 41^{\prime} 33^{\prime \prime} \mathrm{E}$ (O. Mirshamsi).

COMMENTS. Hitherto, this species was known from Central Asia [Marusik, Logunov, 1995]. Our record lies in the southernmost limit of the known species' range.

\section{Xysticus cf. kaznakovi Utochkin, 1968}

MATERIAL. Khorasan-e Razavi Prov.: $1 \sigma^{7}$ (ZMFUM), Torbat-e Jam road, Ebdal Abad ( $\left.35^{\circ} 23^{\prime} 07^{\prime \prime} \mathrm{N}, 60^{\circ} 13^{\prime} 53^{\prime \prime} \mathrm{E}\right)$, April 2013 , S. Saneei.

COMMENTS. X. kaznakovi was described from Turkmenistan and is currently known from Macedonia, and then from Azerbaijan to Tajikistan [WSC, 2015]. However, our identification is to be considered provisional, as this species has been identified on the basis of a single male (the present material may also belong to an undescribed species).

Family Titanoecidae

Titanoeca schineri C.L. Koch, 1872

Figs 47-52.

MATERIAL. Mazandaran Prov.: $20^{7} \sigma^{7}, 1+$ (ZMFUM), Veresk $\left(52^{\circ} 67^{\prime} \mathrm{N}, 35^{\circ} 51^{\prime} \mathrm{E}\right)$, May 2015 , A. Zamani.

COMMENTS. This species has a west-Palaearctic distribution [WSC, 2015].

Family Trachelidae

Trachelas minor O. Pickard-Cambridge, 1872 Figs 53-56.

MATERIAL. $1 \bigcirc^{\top}, 1+$ (ZMMU), the label was lost, probably collected in Fars Prov. in 2000.

COMMENTS. This species is known from the Mediterranean to Central Asia, and also from West Africa [WSC, 2015]. Hitherto, only the genus Trachelas was reported from Iran [Mozaffarian et al., 2000], without an exact identification of the species.

\section{Conclusions}

Based on the results of the present study, the family Miturgidae, seven genera and 30 species of spiders have been recorded from Iran for the first time. Among the recorded genera, Agelescape (Agelenidae), Dictyna (Dictynidae), Firmicus (Thomisidae), Paracedicus (Cybaeidae), Poecilochroa, Sidydrassus (Gnaphosidae) and Prochora (Miturgidae) have been recorded from the country for the first time. Of the studied material, records of nine species (Agelescape gideoni, Benoitia lepida, Trachyzelotes pedestris, Hersiliola simoni, $H$. turcica, Evippa caucasica, Prochora lycosiformis, Steatoda ephippiata, Firmicus dewitzi) represent the eastern- or south-easternmost limits of the corresponding species' range, those of six species (Paracedicus gennadii, Poecilochroa senilis, Sidydrassus shumakovi, Plexippoides gestroi, Enoplognatha turkestanica, Xysticus turkmenicus) — the southernmost range limits, and that of Eusparassus kronebergi - the westernmost limit of its range. The presence of Benoitia lepida (Agelenidae) in Iran, which was earlier considered doubtful, has been confirmed by the recently collected material from north-eastern Iran. Given the aforementioned records, the total number of spider species recorded from Iran is now 592 species [cf. Zamani et al., 2016].

ACKNOWLEDGEMENTS. We are most grateful to Peter J. Schwendinger (MHNG) for providing us with locality details of the specimen collected by Antoine Senglet, Alireza Naderi (Department of Environment, Iran) for his invaluable help with the study of spider material deposited in the National Museum of Natural History \& Genetic Resources (Iran), Denis Kasatkin (Moscow, Russia) for providing us with his spider material from Iran and the Green Chya Environmental NGO (Iran) for organizing the collecting trip of the first author and his team to Kurdistan Prov. This study was partly supported by the office of research affairs, Ferdowsi University of Mashhad (project no. 3/37310).

\section{References}

Bolzern A. 2015. Benoitia lepida (O. Pickard-Cambridge, 1876) in Agelenids of the World. Online at: http:/cite.scratchpads.eu/ agelenidsoftheworld.myspecies.info/2015-12-10/Benoitia-lepida-O.-Pickard-Cambridge-1876.pdf (accessed 10 December 2015).

Brignoli P.M. 1977. Sur quelques Agelenidae et Hahniidae (Araneae) d'Afrique du Nord // Revue Arachnologique. T.1. P.13-21.

Charitonov D.E. 1946. New forms of spiders of the USSR // Izvestija Estedvenno-Nauchnogo Instituta pri Molotovskom Gosudarstvennom Universitete imeni M. Gor'kogo. Vol.12. No.3. P.19-32, 2 tabs.

Esyunin S.L., Tuneva T.K. 2002. A review of the family Gnaphosidae in the fauna of the Urals (Aranei), 1. Genera Drassodes Westring, 1851 and Sidydrassus gen.n. // Arthropoda Selecta. Vol.10 (for 2001). No.2. P.169-180.

Fet V. 1993. The spider genus Cedicus Simon 1875 (Arachnida Aranei Agelenidae) from Middle Asia // Arthropoda Selecta. Vol.2. No.1. P.69-75.

Guseinov E.F., Marusik Yu.M., Koponen S. 2005. Spiders (Arachnida: Aranei) of Azerbaijan 5. Faunistic review of the funnelweb spiders (Agelenidae) with the description of a new genus and species // Arthropoda Selecta. Vol.14. No.2. P.153-177.

Helsdingen P.J. van. 2014. Fauna Europaea: Araneae, version 2.6. online at: http://www.faunaeur.org (accessed 30 September 2014).

Kashefi R., Ghassemzadeh F., Kami H.G., Mirshamsi O. 2013. New data on spider fauna from Golestan Prov., Iran (Arachnida, Araneae) // Progress in Biological Sciences. Vol.3. P.7-22.

Levy G. 1985. Araneae: Fauna Palaestina, Arachnida II. Thomisidae. Jerusalem: Israel Academy of Sciences and Humanities. 115 pp. 
Levy G. 1996. The agelenid funnel-weaver family and the spider genus Cedicus in Israel (Araneae, Agelenidae and Cybaeidae) // Zoologica Scripta. Vol.25. P.85-122.

Levy G. 2003. Spiders of the families Anyphaenidae, Hahniidae, Ctenidae, Zoridae, and Hersiliidae (Araneae) from Israel // Israel Journal of Zoology. Vol.49. P.1-31.

Logunov D.V., Marusik Yu.M., Mozaffarian F. 2002. Faunistic review of the jumping spiders of Iran (Aranei: Salticidae) // Arthropoda Selecta. Vol.10 (for 2001). No.2. P.155-167.

Logunov D.V., Mirshamsi O., Musavi S., Shayestehfar A. 2013. New faunistic records of Salticidae (Aranei) from Khorasan Prov. of Iran // Arthropoda Selecta. Vol.22. No.4. P.379-381.

Marusik Yu.M., Guseinov E.F., Koponen S. 2003. Spiders (Arachnida: Aranei) of Azerbaijan. 2. Critical survey of wolf spiders (Lycosidae) found in the country with description of three new species and brief review of Palaearctic Evippa Simon, 1885 // Arthropoda Selecta. Vol.12. No.1. P.47-65.

Marusik Yu.M., Kunt K.B., Ya mur E.A. 2010. A new species of Hersiliola Thorell, 1870 (Araneae, Hersiliidae) from Turkey // ZooKeys. Vol.37. P.27-34.

Marusik Yu.M., Logunov D.V. 1995. The crab spiders of Middle Asia (Aranei, Thomisidae), 2 // Beiträge zur Araneologie. Bd.4 P.133-175.

Marusik Yu.M., Nadimi A., Omelko M.M., Koponen S. 2014a First data about cave spiders (Arachnida: Araneae) from Iran // Zoology in the Middle East. Vol.60. No.3. P.255-266.

Marusik Yu.M., Zamani A. 2015a. The spider family Filistatidae (Araneae) in Iran // ZooKeys. Vol.516. P.123-135.

Marusik Yu.M., Zamani A. 2015b. Additional new species of Filistatidae (Aranei) from Iran // Arthropoda Selecta. Vol.24 No.4. P.429-435.

Marusik Yu.M., Zamani A., Mirshamsi O. 2014b. Three new species of mygalomorph and filistatid spiders from Iran (Araneae, Cyrtaucheniidae, Nemesiidae and Filistatidae) // ZooKeys. Vol.463. P.1-10.

Mikhailov K.G. 2013. The spiders (Arachnida: Aranei) of Russia and adjacent countries: a non-annotated checklist // Arthropoda Selecta. Suppl.3. P.1-262.

Mirshamsi O., Marusik Yu.M., Jamili E. 2013a. The spider family Hersiliidae Thorell, 1870 (Arachnida: Araneae) in Iran // Zoology in the Middle East. Vol.59. No.4. P.347-352.

Mirshamsi O., Marusik Yu.M., Zamani A., Moradmand M., Kashefi R. 2015. Fauna Iranica: I. Annotated checklist of the spiders of Iran (Arachnida: Araneae) // Iranian Journal of Animal Biosystematics. Suppl.1. P.1-108.

Mirshamsi O., Shayestehfar A., Musavi S., Hamta A. 2013b. New data on the jumping spiders from northeast of Iran (Aranei: Salticidae) // Iranian Journal of Animal Biosystematics. Vol.9. P.117-123.
Moradmand M. 2013. The stone huntsman spider genus Eusparassus (Araneae: Sparassidae): systematics and zoogeography with revision of the African and Arabian species // Zootaxa. Vol.3675. P.1-108.

Moradmand M., Jäger P. 2011. A review on the huntsman spider genus Spariolenus Simon, 1880 (Araneae: Sparassidae: Heteropodinae) in Iran with description of four new species // Zootaxa. Vol.2910. P.46-62.

Moradmand M., Jäger P. 2012. Taxonomic revision of the huntsman spider genus Eusparassus Simon, 1903 (Araneae: Sparassidae) in Eurasia // Journal of Natural History. Vol.46. P.2439-2496.

Mozaffarian F., Tirgari S., Bayat-Asadi H. 2000. [Investigations on the fauna of spiders in paddy fields of Mazandaran and Gilan Provinces] // Applied Entomology and Phytopathology. Vol.67. P.51-70 [in Persian].

Nentwig W., Blick T., Gloor D., Hänggi A., Kropf C. 2015. Spiders of Europe. Version 2015, online at: http://www.araneae.unibe.ch (accessed 10 December 2015).

Ono H., Martens J. 2005. Crab spiders of the families Thomisidae and Philodromidae (Arachnida: Araneae) from Iran // Acta Arachnologica. Vol.53. P.109-124.

Schwendinger P.J. 1990. A synopsis of the genus Atypus (Araneae, Atypidae) // Zoologica Scripta. Vol.19. P.353-366.

Tanasevitch A.V. 2008. On linyphiid spiders (Araneae) collected by A. Senglet in Iran in 1973-1975 // Revue Suisse de Zoologie. T.115. Fasc.3. P.471-490.

Tanasevitch A.V. 2009. The linyphiid spiders of Iran (Arachnida, Araneae, Linyphiidae) // Revue Suisse de Zoologie. T.116. Fasc.3-4. P.379-420.

WSC 2015. World Spider Catalog, Natural History Museum Bern. Version 16.5, online at: http://wsc.nmbe.ch (accessed 25 December 2015).

Zamani A. 2015. The spider collection (Arachnida: Araneae) of the Zoological Museum of the Iranian Research Institute of Plant Protection, with new species records for Iran // Arachnologische Mitteilungen. Vol.50. P.11-18.

Zamani A., Mirshamsi O., Jannesar B., Marusik Y.M., Esyunin S.L. 2015. New data on the spider fauna of Iran (Arachnida: Araneae), Part II // Zoology and Ecology. Vol.25. No.4. P.339-346.

Zamani A., Mirshamsi O., Marusik Yu.M., Moradmand M. 2016. Checklist of Spiders of Iran. Version 2015, online at: http:// www.spiders.ir (accessed 15 January 2016).

Zamani A., Nikmagham Z., Allahdadi M., Ghassemzadeh F., Mirshamsi O. 2014. New data on the spider fauna of Iran (Arachnida: Araneae) // Zoology in the Middle East. Vol.60. P.362-367.

Responsible editor D.V. Logunov 